\title{
Examination of Burnout Levels of Athletes Studying at the Faculty of Sport Sciences
}

\author{
Erol Doğan \\ Correspondence: Erol Doğan, Sports Sciences Faculty, Ondokuz Mayıs University, Samsun, Turkey.
}

Received: May 7, $2019 \quad$ Accepted: May 19, $2019 \quad$ Online Published: May 22, 2019

doi:10.11114/jets.v7i7.4257 URL: https://doi.org/10.11114/jets.v7i7.4257

\begin{abstract}
The aim of this study is to investigate burnout levels of athletes studying at the faculty of sports sciences. 250 students (female; 102, male; 148) who study in Ondokuz Mayıs University, at the Faculty of Sport Sciences and actively participate in sports life were included in the study. The 5-point Likert-type sports burnout scale developed by Raedeke and Smith (2001) and adapted to Turkish by Kelecek et al.(2016) was used to determine the burnout levels of the subjects. SPSS 22.0 program was used in the statistical analysis of the study. When the results of the study were examined, in gender, team and individual athletes status and in emotional / physical, declining sense of success in section variables, in none of the sensitization sub-dimensions no statistically significant difference was found ( $p>0.05$ ). As a result, it is thought that the absence of significant difference in the levels of athletic burnout in the findings of the current research may be due to the subject groups' actively continuing sports, studying at the same faculty and and therefore having the same intensity courses. However, in future researches, when examined with variables such as individually separation of branches, training densities, league levels they play and classes, it is thought that it may make a difference.
\end{abstract}

Keywords: burnout; team sports, individual sports, student

\section{Introduction}

The concept of burnout was first proposed by Freudenberger in 1974. Freudenberger (1974) noticed a number of changes in himself in his busy schedule and occurring in other employees and started research and observation on this concept that he thought that this concept affected effectiveness and productivity as psychosocial structures negatively. Burnout means "failure, tiredness or becoming exhausted because of excessive demand in energy, strength or sources" with its dictionary meaning (Eklund and Cresswell, 2007). After the concept of burnout was proposed and since a special measurement tool special for this concept was developed by Maslach and Jackson (1981), he has examined it in different areas and tried to reveal the effects of burnout on the life of the individual (Selçukoğlu, 2001; Govardhan et al., 2012; Kılıç \& Yazıc1, 2012; Suner et al., 2013; Casteneda et al., 2011).

Athletes make a great effort to reach success or to continue their success in sports environment requiring dense competition both physical and psychologically. The emotional states athletes live in the face of this difficult situation appears as an important variable for sportive performance and besides, it attracts the interest of researchers (Kelecek \& Göktürk, 2017). People engaged in sports amateur or professionally go through a long and difficult process to catch a high-level performance and while going through this process, they face many physical and psychological difficulties. The challenges they face reveal both physical and psychological wears in athletes unintentionally. Smith (1986) defined athletes burnout as an incompatible response given to stress associated with exercise and competition, similar to the reasons associated with the job of the employees and reasons causing stress. As to Raedeke (1997) and Raedeke and Smith (2001), they mentioned burnout concept as an emotional and physical exhaustion, reduced sense of achievement and multidimensional psychological syndrome characterized by depersonalization. The special burnout scale for athletes was developed by Raedeke and Smith (2001) and therfore it has been the center of attention in short process by modern day sports scientists and scientists working in the field of psychology. The relationship between burnout in athletes and many psycho-social parameters such as anxiety, perfectionism, team conflicts, loyalty, communication skills and life satisfactions, job satisfaction, doping use has been studied by many sicientists and its relationship with many of these concepts has been revealed (Appleton et al., 2009; Cremades \& Wiggins, 2008; Cremades et al., 2011; Kelecek \& Göktürk, 2017; Kelecek \& Göktürk, 2018; Afyon \& Işıkdemir, 2013; Doğan, 2016; Akbulut \& Altınkök , 2018; Beşiktaş, 2016). 
In the literature review, although there were many studies on burnout and psycho-social researches in athletes (Doğan et al., 2018; Koç and Ermiş, 2016; Kabadayı et al., 2017; Cavusoglu et al., 2017; Bostancı et al., 2017; Ermiş, 2019). it has been observed that burnout levels of the athletes active in sports and studying in different departments of the faculty of sports sciences were not examined. Based on this information, The purpose of the present research is to examine the burnout levels of the students who are both in the sport and studying at the sports sciences faculty.

\section{Method}

\subsection{Study Design}

250 students (female; 102, male; 148) who study in Ondokuz Mays University, at the Faculty of Sport Sciences and actively participate in sports life were included in the study. The 5-point Likert-type sports burnout scale developed by Raedeke and Smith (2001) and adapted to Turkish by Kelecek et al.(2016) was used to determine the burnout levels of the subjects. The participants filled in informed consent form and they were told that it was important to read the questions and fill in the questionnaire form carefully in terms of the validitiy and reliability of the study.

\subsection{Athlete Burnout Scale}

Athlete Burnout Scale was developed by Raedeke and Smith (2001) to determine the level of sports-specific burnout levels of athletes. Scale rated in 5-point Likert scale consists of 3 sub-dimensions (emotional / physical, reduced sense of success, depersonalisation) and 15 items. Turkish adaptation study of athlete burnout scale was done by Kelecek et al., (2016). In the adaptation study, it was observed that items were seen to be collected in the sub-dimensions indicated on the original scale and its three-factor structure was preserved. However, 2 items in the scale were removed due to low factor load and the scale was evaluated through 13 items. In the current study, consistency coefficient values for Cronbach Alpha were determined as 0.83 for Emotional / Physical Burnout sub-dimension, 0.71 for Reduced Sense of Success sub-dimension, and 0.79 for Desensitization sub-dimension.

\subsection{Data Analysis}

22.00 SPSS package program was used for data analysis. The data obtained as a result of the scale was calculated according to the scoring instruction. When evaluating the data, conformity to normal distribution was researched by "Kolmogorov Smirnov Test" and all data were found to be within normal distribution. T-test and one-way variance analysis were conducted for comparision.

\section{Results}

Table 1. Comparison of the burnout levels according to gender variable.

\begin{tabular}{c|c|c|c|c|c}
\hline & Gender & $\mathrm{N}$ & Mean & S.d & t-test \\
\hline \multirow{2}{*}{ Burnout } & Female & 102 & 12.44 & 4.15 & \multirow{2}{*}{1.26} \\
\cline { 2 - 5 } & Male & 148 & 11.79 & 3.91 & 3.44 \\
\hline \multirow{2}{*}{$\begin{array}{c}\text { Depersonalizatio } \\
\mathrm{n}\end{array}$} & Female & 102 & 9.36 & 3.03 & \multirow{2}{*}{0.63} \\
\cline { 2 - 5 } \begin{tabular}{c} 
Competence \\
\cline { 2 - 5 }
\end{tabular} & Male & 148 & 9.10 & 2.50 & \multirow{2}{*}{-0.60} \\
\cline { 2 - 5 }
\end{tabular}

When the burnout levels of subjects were examined according to gender variable, no statistical significance was found in all sub-dimensions ( $\mathrm{p}>0.05)$ ( Table 1$)$.

Table 2. Comparison of the athletes burnout levels according to their being team and individual athletes.

\begin{tabular}{c|c|c|c|c|c}
\hline & & $\mathrm{N}$ & Mean & S.d & t-test \\
\hline \multirow{3}{*}{ Burnout } & Team Sport & 132 & 12.09 & 4.10 & \multirow{2}{*}{0.14} \\
\cline { 2 - 5 } & Individual Sport & 118 & 12.02 & 3.94 & \multirow{2}{*}{0.41} \\
\hline \multirow{2}{*}{$\begin{array}{c}\text { Depersonalizatio } \\
\mathrm{n}\end{array}$} & Team Sport & 132 & 9.29 & 2.98 & 3.44 \\
\cline { 2 - 5 } Competence & Individual Sport & 118 & 9.12 & 2.72 & \multirow{2}{*}{-0.39} \\
\cline { 2 - 5 } & Team Sport & 132 & 10.40 & 2.51 & \\
\cline { 2 - 5 } & Individual Sport & 118 & 10.53 & & \\
\hline
\end{tabular}

When the burnout levels of subjects were examined according to their being team and individual athletes, no statistical significance was found in all sub-dimensions ( $p>0.05)$ (Table 2). 
Table 3. Comparison of the athletes burnout levels according to departments they study.

\begin{tabular}{|c|c|c|c|c|c|}
\hline & & $\mathrm{N}$ & Mean & S.d & $\mathrm{F}$ \\
\hline \multirow{4}{*}{$\begin{array}{c}\text { Burnout } \\
\text { Depersonalization }\end{array}$} & Teaching & 80 & 11.53 & 4.40 & \multirow{4}{*}{2.46} \\
\hline & Coaching & 74 & 13.08 & 4.02 & \\
\hline & $\begin{array}{c}\text { Sports } \\
\text { Management }\end{array}$ & 69 & 11.86 & 3.48 & \\
\hline & Recreation & 27 & 11.33 & 3.74 & \\
\hline \multirow{4}{*}{$\begin{array}{l}\text { Competence } \\
\text { Burnout }\end{array}$} & Teaching & 80 & 9.15 & 3.65 & \multirow{4}{*}{1.75} \\
\hline & Coaching & 74 & 9.57 & 3.03 & \\
\hline & $\begin{array}{c}\text { Sports } \\
\text { Management }\end{array}$ & 69 & 9.38 & 3.04 & \\
\hline & Recreation & 27 & 7.96 & 2.39 & \\
\hline \multirow{4}{*}{ Depersonalization } & Teaching & 80 & 10.09 & 2.56 & \multirow{4}{*}{1.24} \\
\hline & Coaching & 74 & 10.88 & 2.67 & \\
\hline & $\begin{array}{c}\text { Sports } \\
\text { Management }\end{array}$ & 69 & 10.54 & 2.63 & \\
\hline & Recreation & 27 & 10.26 & 2.57 & \\
\hline
\end{tabular}

When the burnout levels of subjects were examined according to departments they study, no statistical significance was found in all sub-dimensions ( $\mathrm{p}>0.05)$ (Table 3).

\section{Discussion}

When analyzed the current research results, no statistical significance was found ( $p>0.05)$ according to being individual and team athletes of the students studying in sports science and according to their gender and departmental variability. The results revealed similar results in terms of athletes burnout status studying at sports sciences faculties and continuing active sport life.

When analyzed the conducted researches in the literature, they are many researches about the burnout levels in athletes. Increased burnout levels of athletes shows that it causes reduced levels of motivation (Gustafsson et al.,2008; Lemyre et al., 2007; Londsdale et al., 2009), increased anxiety levels and decreased self-confidence (Cremades et al., 2011), increase in stress levels (Tabei et al., 2012) and feeling desperate ( Gustafsson et al., 2010). Besides that, it has also been specified in the conducted researches that ego-oriented individuals (Isoard - Gautheur et al., 2013), individuals having obsessive passion (Gustafsson et al., 2011), and perfectionists (Appleton et al., 2009; Chen et al., 2009; Hill \& Appleton, 2011; Hill et al., 2010) had higher burnout levels. Kelecek and Göktürk (2010) identified in their research on female footballers that as the loyalty of athletes to their teams increases, burnout levels decrease. Kelecek and Göktürk (2018) also stated in their research on male footballers that level of motivation and commitment influence burnout levels on athletes significantly. Besides, they have reported that athletes' feelings during sporting performance provide information about burnout process.

The relationship between the concept of burnout and different psychological concepts was also proved in the study conducted by using athlete burnout scale. Within the scope of this purpose, when analyzed the related literature, it has been observed that burnout concept in athletes is in a positive relationship with negative emotion states and in a negative relationship with positive emotion or psychological traits. Cremades et zl., (2011) discovered positive relationship between cognitive and physical anxiety and burnout levlels, Gustaffson et all., (2011) discovered positive relationship between obsessive passion and burnout, Lemyre et al., (2007) discovered positive relationship between overtraining and burnout, Smith et al., (2010) discovered positive relationship in team conflicts in athletes. In addition, many conducted researches found negative relationship between motivation and athlete burnout (Gustaffson et al., 2008; Lemyre et al., (2007); Londsdale et al., 2009; DeFreese \& Smith, 2013). Curran et al., (2011) discovered negative relationship between compatible passion and athlete burnout, Cremades et al., (2011) discovered negative relationship between self-confidence and athlete burnout in their researches. These results clearly show that burnout status of athletes together with their negative emotion states show parallelism with athlete burnout. However, it is observed that as their positive emotion states increase, levels of burnout decrease. The burnout results of athletes participating in our current research showed high results as regards to a lot of researches. These results are thought to result from both the subjects' continuing their active sports life and continuing their university education intensively. The burnout levels are considered to be high because being active and at the same time continuing his education, the athlete feels psychologically under pressure during course, training and competition processes. Therefore, similar results in our research findings are based on these reasons. In order to decrease the burnout levels of active athletes continuing their education lives at universities, it has been thought that signing specific protocols between universities, sport clubs and federations can affect the burnout levels and sports lives of the students continuing their sports positively. Furthermore, researches conducted by studying and comparing the general 
burnout status of the students either doing or not doing sports will be able to contribute to make more clear comments about the burnout level of the athletes studying at the universities.

\section{References}

Afyon, Y. A., \& Işıdemir, E. (2013). Futbol Antrenörlerinin İletişim Becerileri, Tükenmişlik Düzeyleri ve Yaşam Tatminleri Arasındaki İlişkinin İncelenmesi. International Journal of Human Sciences, 10(1), 1705-1716.

Akbulut, A., \& Altinkök, M. Boks Antrenörlerinin Tükenmişlik Düzeylerinin İncelenmesi. Sportive, 1(1), 31-41.

Appleton, P. R., Hall, H. K., \& Hill, A. P. (2009). Relations between multidimentional perfectionism and burnout in junior-elite male athletes. Psychology of Sport and Exercise, 10, 457-465. https://doi.org/10.1016/j.psychsport.2008.12.006

Beşiktaş, M. Y. (2016). Doping Kullanan Erkek Vücut Geliştirme Sporcularının Yarışma Sonrası Tükenmişlik Durumlarının Ölçülmesi. İstanbul Üniversitesi Spor Bilimleri Dergisi, 6(3), 13-21.

Bostanc1, Ö., Oda, B., Şebin, K., \& Erail, S. (2017). 11-13 Yaş Öğrencilerin Spor Yapma Durumlarına Göre İyimserlik İle Saldırganlık Düzeylerinin İncelenmesi. Beden Eğitimi ve Spor Bilimleri Dergisi, 19(4), 205-217.

Castaneda, A. E., Suvisaari, J., Marttunen, M., Perälä, J., Saarni, S. I., \& Aalto-Setälä, T. (2011). Cognitive functioning in relation to burnout symptoms and social and occupational functioning in a populationbased sample of young adults. Nordic Journal of Psychiatry, 65(1), 32-39. https://doi.org/10.3109/08039488.2010.485328

Cavusoglu, G., Yılmaz, A. K., Kabadayı, M., Abacı, S. H., \& Tasmektepligıl, M. Y. (2017). Comparison of narcissism levels of students in the faculty of sports sciences in terms of some demographic variables. Turkish Journal of Sport and Exercise, 19(2), 150-156. https://doi.org/10.15314/tsed.296702

Chen, L. H., Kee, Y. H., \& Tsai, Y. (2009). An examination of the dual model of perfectionism and adolescent athlete burnout: A short-term longitudinal research. Social Indicators Research, 91, 189-201. https://doi.org/10.1007/s11205-008-9277-9

Cremades, J. G., Wated, G., \& Wiggins, M. S. (2011). Multiplicative measurements of a trait anxiety scale as predictors of burnout. Measurement in Physical Education and Exercise Science, 15, 220-233. https://doi.org/10.1080/1091367X.2011.594356

Curran, T., Appleton, P. R., Hill, A. P., \& Hall, H. K. (2011). Passion and burnout in elitejunior soccer players: The mediating role of self-determined motivation. Psychology of Sport and Exercise, 655-661. https://doi.org/10.1016/j.psychsport.2011.06.004

DeFreese, J. D., \& Smith, A. L. (2013). Teammate social support, burnout and self-determined motivation in collegiate athletes. Psychology of Sport and Exercise, 14, 258 - 265. https://doi.org/10.1016/j.psychsport.2012.10.009

Doğan, E., Yılmaz, A. K., Kabadayı, M., \& Mayda, M. H. (2018). Spor Bilimleri Öğrencileri İle Farklı Fakültelerde Okuyan Öğrencilerin Sosyalleşme Ve Mutluluk Düzeylerinin İncelenmesi. Kafkas Üniversitesi Sosyal Bilimler Enstitüsü Dergisi, 22, 403-411.

Doğan, M. (2016). Taekwondo antrenörlerinin iş doyumu ve tükenmişlik düzeylerin incelenmesi (Doctoral dissertation, Selçuk Üniversitesi Sağlık Bilimleri Enstitüsü).

Eklund, R. C., \& Cresswell, S. L. (2007). Athlete Burnout. (G Tenenbaum, RC Eklund eds.) Handbook of Sport Psychology, 621-641. John Wiley \& Sons Inc. https://doi.org/10.1002/9781118270011.ch28

Freudenberger, H. J. (1974). Staff burnout. Journal of Social Issues, 30(1), 159-165. https://doi.org/10.1111/j.1540-4560.1974.tb00706.x

Govardhan, L. M., Pinelli, V., \& Schnatz, P. F. (2012). Burnout, depression and job satisfaction in obstetrics and gynecology residents. Connecticut Medicine, 76(7), 389-395. https://doi.org/10.1080/17461391.2010.536573

Gustafsson, H., Hassmén, P., \& Hassmén, N. (2011). Are athletes burning out with passion?.European Journal of Sport Science, 11(6), 387-395.

Gustafsson, H., Hassmen, P., \& Podlog, L. (2010). Exploring the relationship between hope and burnout in competitive sport. Journal of Sport Sciences, 28(14),1495-1504. https://doi.org/10.1080/02640414.2010.521943

Gustafsson, H., Hassmen, P., Kentla, G., \& Johansson, M. (2008). A qualitative analysis of burnout in elite swedish athletes. Psychology of Sport and Exercise, 9, 800-816. https://doi.org/10.1016/j.psychsport.2007.11.004

Hill, A. P., \& Appleton, P. R. (2011). The predictive ability of the frequency of perfectionistic cognitions, self-oriented perfectionism and socially prescribed perfectionismin relation to symptoms of burnout in youth rugby players. Journal of Sports Sciences, 29, 695-703. https://doi.org/10.1080/02640414.2010.551216 
Hill, A. P., Hall, H. K., \& Appleton, P. R. (2010). Perfectionism and athlete burnout in junior elite athletes: The mediating role of coping tendencies. Anxiety, Stress \& Coping, 23(4), 415-430. https://doi.org/10.1080/10615800903330966

Isoard-Gautheur, S., Gulliet-Descas, E., \& Duda, J. L. (2013). How to achieve in elite training centers without burning out? An achievement goal theory perspective. Psychology of Sport and Exercise, 14, 72-83. https://doi.org/10.1016/j.psychsport.2012.08.001

Kabadayı, M., Eski, T., Bayram, L., Yılmaz, A. K., \& Mayda, M. H. (2017). Analysis of the factors which influence participation of university students in recreational activities. European Journal of Education Studies.

Kelecek, S., \& Göktürk, E. (2017). Kadın Futbolcularda Sporcu Bağlılığının Sporcu Tükenmişliğini Belirlemedeki Rolü. Başkent Üniversitesi Sağlık Bilimleri Fakültesi Dergisi-BÜSBID, 2(2).

Kelecek, S., \& Koruç, Z. (2018). Futbolcularin Güdüsel Yönelim Ve Spora Bağlilik Düzeylerinin Sporcu Tükenmişliğini Belirlemedeki Rolü. Başkent Üniversitesi Sağllk Bilimleri Fakültesi Dergisi-BÜSBID, 3(2).

Kelecek, S., Kara, F. M., Kazak, Ç. Z., \& Aş̧̧ı, F. H. (2016). Sporcu Tükenmişlik Ölçeği”nin Türkçe Uyarlaması (The Turkish Adaptation Athlete Burnout Questionnaire") Hacettepe Spor Bilimleri Dergisi, 27(4), 149-161. https://doi.org/10.17644/sbd.311371

Kılıç, I., \& Yazıcı, T. (2012). Study of job satisfaction and professional exhaustion of music teachers in fine arts and sport high schools in terms of some variables. e-Journal of New World Sciences Academy, 7(2), 182- 198.

Koç, H. E., \& Ermiş, E. (2016). Self-compassion as a predictor of social physique anxiety in athletes. Journal of Human Sciences, 13(3), 5214-5222. https://doi.org/10.14687/jhs.v13i3.4120

Lemyre, P. N., Roberts, G. C., \& Stray-Gundersen, J. (2007). Motivation, overtraining, and burnout: Can selfdetermination predict overtraining and burnout in elite athletes?.European Journal of Sport Science, 7, 115-126. https://doi.org/10.1080/17461390701302607

Londsdale, C., Hodge, K., \& Rose, E. (2009). Athlete burnout in elite sport: A self-determination perspective. Journal of Sport Sciences, 27(8), 785-795. https://doi.org/10.1080/02640410902929366

Maslach, C., \& Jackson, S. E. (1981). The measurement of experienced burnout. Journal of Occupational Behaviour, 2, 99-113. https://doi.org/10.1002/job.4030020205

Raedeke, T. D. (1997). Is athlete burnout more than just stress? A sport commitment perspective. Journal of Sport \& Exercise Psychology, 19, 396-417. https://doi.org/10.1123/jsep.19.4.396

Raedeke, T. D., \& Smith, A. L. (2001). Development and Preliminary Validation of An Athlete Burnout Measure. Journal of Sport and Exercise Psychology, 23, 281-306. https://doi.org/10.1123/jsep.23.4.281

Selçukoğlu, Z. (2001). Araştırma Görevlilerinde Tükenmişlik Düzeyi ile Yalnızlık Düzeyi ve Yaşam Doyumu Arasındaki İlişkinin Bazı Değişkenler Açısından Değerlendirilmesi. Yayınlanmamış Yüksek Lisans Tezi. Selçuk Üniversitesi. Sosyal Bilimler Enstitüsü.

Smith, A. L., Gustafsson, H., \& Hassmen, P. (2010). Peer motivational climate and burnout perceptions of adolescent athletes. Psychology of Sport and Exercise, 6, 453-460. https://doi.org/10.1016/j.psychsport.2010.05.007

Smith, R. E. (1986). Toward a Cognitive-Affective Model of Athletic Burnout. Journal of Sport Psychology, 8, 36-50. https://doi.org/10.1123/jsp.8.1.36

Suñer-Soler, R., Grau-Martín, A., Font-Mayolas, S., Gras, M. E., Bertran, C., \& Sullman, M. J. (2013). Burnout and quality of life among Spanish healthcare personnel. Journal of Psychiatric and Mental Health Nursing, 20(4), 305-313. https://doi.org/10.1111/j.1365-2850.2012.01897.x

Tabei, Y., Fletcher, D., \& Goodger, K. (2012). The relationship between organizational stressors and athlete burnout in soccer players.Journal of Clinical Sport Psychology, 6, 146-165. https://doi.org/10.1123/jcsp.6.2.146

\section{Copyrights}

Copyright for this article is retained by the author(s), with first publication rights granted to the journal.

This is an open-access article distributed under the terms and conditions of the Creative Commons Attribution license which permits unrestricted use, distribution, and reproduction in any medium, provided the original work is properly cited. 